\title{
Rhetorical Caricature: An Educational Reading of Nabokov's Treatment of Freud
}

Herner Sæverot, University of Bergen

Email: herner.saverot@psych.uib.no

\begin{abstract}
Vladimir Nabokov (1899-1977), Russian-American novelist and lepidopterist, was neither a didactician nor a moralist. His images, which he painted with his words, are deceptive and contradictory. But the strangest thing happens. It turns out that Nabokov disliked Freud and painted images of the psychoanalyst that seem to become stale and mechanical. Literary critics, philosophers, and others have had a tendency to criticize Nabokov for suffering from influence-anxiety when it comes to Freud, hence making Nabokov into a dull paternalist with strong and prejudiced convictions. My suggestion is that we go beyond the 'anxiety of influence' viewpoint and address the issue through a phenomenological study and base our judgments on the experiences of the phenomena that shine through different texts of Nabokov. Thus it will be possible to see, I argue, that Nabokov's rhetorical caricature may evoke experiences that are educative. At the same time, Nabokov's treatment of Freud can be cast in a new light.
\end{abstract}

\section{Introduction}

Sigmund Freud is considered to be one of the most influential and most important thinkers of the twentieth century. His theories and ideas have become interwoven into the very fabric of our culture. They have helped shape our views on a broad range of subjects, including, of course, psychology and psychotherapy, but also sexuality, childhood, education, religion, memory, personality and so forth. Freudian terms - such as "a Freudian slip," "repression," "denial” - appear regularly in our everyday language. Vladimir Nabokov is one person however who refused to think and talk in a Freudian manner. He would not join the crowd. Rather, he sought to preserve his claim to speak in his own particular way. A major reason for this was that he thought Freud's work and theories were too inclined towards general ideas (see, for example, Stegner, 1966; Field, 1967; Boyd, 1991; Wood, 1994; De la Durantaye, 2007). According to Nabokov (1996b), Freud overlooked the complexity of life; Nabokov believed that Freudian theory was overly deterministic and that it attempted to predict answers to all kinds of problems. But such a way of thinking does injustice to our past events. Nabokov (1973) believed that those things that have happened to us in life are always impossible to grasp in exact ways because they are so complex. Hence, those who adhere to Freud's theories are doomed to draw a distorted picture of reality. 
Most often Nabokov's secrets, as they appear in his novels, are so well hidden that they are very difficult to spot (see Sæverot, 2010), but when it comes to his treatment of Freud he nearly shouts, so to speak, from the rooftops. From these examples, it is impossible to miss Nabokov's true thoughts on Freud. For Nabokov, Freud is a fool, but a fool who poses a potential danger. That is to say, for Nabokov, the Freudian quest for Truth can easily lead us into a type of hallucinatory world. Accordingly, those who interpret everything symbolically will come to be deceived since all matters become simply reduced to representations of one's own thoughts and beliefs.

This is not the only educational insight the reader can gain from Nabokov's ridiculing of Freud. Nabokov is painting an exaggerated and oversimplified portrait of Freud, a caricature image in a sense - a deceitful image even. Rhetorical caricature has the power, I claim in this

paper, to educate. It is in fact the very contradiction and incongruity of Nabokov's picture of Freud that creates a space for education. That is to say, it can allow the reader to stop, hesitate, go beyond well-worn ideas of Freud and perhaps life in general.

This of course is an unorthodox and perhaps original way of teaching. A traditional teacher has, rather, a tendency to communicate straightforwardly (even though being too direct and too didactic is seldom a fruitful strategy when it comes to educating others (Cf. Sæverot, 2010). In other words, a didactic and moralising approach is unlikely to change another's way of thinking and behaving. Nabokov, on the other hand, strives to help - like any good teacher would - even though the recipient of this help might not perceive that he or she is being helped. The 'invisible helping hand' is due to the very complex ways in which Nabokov communicates and, we should add, teaches. Nabokov is the kind of teacher who tries to touch and move his readers in a non-didactic manner (Sæverot, 2010). One cannot, however, guarantee whether the reader will be sufficiently educated via a style or technique of rhetorical caricature. The rhetorical caricature employed by Nabokov is, in other words, risky. Nevertheless, caricatures may be a powerful contribution to education because such exaggerations can bring us, at least now and then, to see accepted phenomena anew.

An educational reading of Nabokov's treatment of Freud can be problematic, though, because of the unpredictable and uncertain nature of the messages in Nabokov's writing. Messages are deceptively concealed and can be neither seen nor heard when read technically or instrumentally (which as we will see has often been the case). Let me be clear then about what is embedded in the novelist's communication regarding Freud: it equates to a vast complex of deception which is not readily revealed by technical methods, and is not revealed by materialist theories. That is why I will attempt to move beyond such methods and theories and employing rather a phenomenological perspective on Nabokov's treatment of Freud.

\section{The Case: Nabokov's Treatment of Freud}

Nabokov's novels are like a dance of trickery; they are full of complexity and deceitfulness and the reader is always left with a feeling of uncertainty. Nabokov himself always stood between things. He stood, for example between the Russian and the American language, reality and metaphysics, lepidopterology and authorship etc. His texts, too, are highly contradictory and, because of this, can never quite be understood once and for all. However, when it comes to Freud, things are apparently different. In his treatment of Freud, Nabokov becomes a man of unwavering opinion. In his criticism and mocking of the psychoanalyst, his complete contempt of Freud comes through. For example, during a French television 
interview: "I admire Freud greatly ... as a comic writer" (Cited by De la Durantaye, 2007, p. 118). Antipathy to Freud is also reflected in the foreword to the novel Bend Sinister (1947) where he writes: "all my books should be stamped Freudians, Keep Out" (Nabokov, 1996a, pp. 168-169). These examples point to how Nabokov steps into the scene as an authoritative author who all but forbids his readers to dawn psychoanalytic lenses.

In the novel Lolita (1955), there is a substantial amount of this mocking of Freud. The protagonist-narrator of the novel, Humbert, points out that "[w]e must remember that a pistol is the Freudian symbol of the Ur-father's central forelimb” (Nabokov, 1971, p. 218). In doing so he immediately turns the reader's attention towards Freud's use of symbols. The same thing happens where Humbert holds his gun in the presence of Lolita's husband, Dick Schiller. At the same time he is imagining that he is to gun down the playwright and pornographic filmmaker Clare Quilty (the man who stole Lolita away from him), "and then pulled the pistol's foreskin back, and then enjoyed the orgasm of the crushed trigger: I was always a good little follower of the Viennese medicine man [Freud]" (p. 276). Humbert's sleight of hand is here holding Freudian symbolism up to ridicule. That is quite obvious since the narrator's wish to murder Dick ends up with a homosexual fantasy. ${ }^{1}$ The point seems to be that Freud's thinking is "box like," limited and thereby comical.

In the novel, Humbert is also being ridiculed by Nabokov. The protagonist claims that Freud is both funny and foolish, but strangely he ends up believing in the ideas of Freud. This almost unbelievable paradox is noticed by Michael Wood:

We are left with the feeling, not that the Annabel affair simply set the pattern for Humbert's later life, but that he pretty much believes that it did, in spite of his doctor-baiting antics - and to that extent it actually does set the pattern. Humbert's showy self-consciousness, I think, adds up to something less than scepticism: he really is saying what he pretends he is only pretending to say. (Wood, 1994, p. 121)

Wood here is referring to "the Annabel affair." To understand his point, it would be prudent to discuss 'the affair' that appears early in Lolita.

Humbert returns to a childhood memory, a typical Freudian move. He remembers Annabel Leigh, his first love, who is named after the woman in Edgar Allan Poe's poem Annabel Lee. ${ }^{2}$ It was summer time, and they were both thirteen years old. The love story however ended in a tragedy; Annabel died of typhus only four months later. Humbert returns to this memory, again and again, always wondering if this experience itself was the cause of his abnormal sexual orientation: ${ }^{3}$ "I leaf again and again through these miserable memories, and keep asking myself, was it then, in the glitter of that remote summer, that the rift in my life began [...]?” (Nabokov, 1971, p. 15). Soon after this he gives an affirmative yes to the question: "I am convinced, however, that in a certain magic and fateful way Lolita began with Annabel" (pp. 15-16). Thus Humbert is stating what he "pretends he is only pretending to say.” That is, he ends up being a Freudian even though he pokes fun at Freud throughout his memoir. In the end, Humbert does not question his answer; the cause, to him, has been firmly established.

In several ways Humbert resembles the Freud of the book Leonardo da Vinci and a Memory of His Childhood (1910). This book certainly has its complexities. From a certain point of view the reader can see that Freud gives the impression that psychoanalysis is a tool 
that can solve a myriad of psychological problems. A particular childhood memory of Leonardo da Vinci ${ }^{4}$ is its point of departure. By analysing this memory with the help of the psychoanalytic method, the divine tool, it is, according to Freud, possible to find the causes of da Vinci's claimed homosexuality. I suggest that the book Leonardo da Vinci and a Memory of His Childhood has similarities with the Annabel example. Freud, as Nabokov's protagonist, is turning to the past in order to find the cause of sexual orientation. Furthermore, this particular voice of Freud is very similar to Humbert's. They are both very certain to have solved the riddle or uncovered the truth. The method of digging to the bottom of a person's forgotten or suppressed past (psychobiography), reveals the truth or solves the riddle. ${ }^{5}$

The reader may think that since the protagonist is a follower of Freud's psychoanalysis, then so too is the author. I argue that the passages wherein Humbert is mimicking Freud are nothing but a decoy and, as such, an example of Nabokov's stylistic deception. In other words, Nabokov lets Humbert imitate a particular Freud - the Freud who is a follower of Cartesian certainty or who believes that psychoanalysis is the ultimate method. But why is Nabokov doing this? I argue that he is playing games with what is commonly perceived as Freud's dogmatism. Rules, certainty and symbolic meanings are to Nabokov nothing but deception.

A number of Nabokov readers have highlighted the disdain for Freud in his writing. However, I argue that what Nabokov is communicating contains deceptively concealed incongruities that are not to be found in the deepest depths of the novel. What makes it difficult to find these incongruities is that Nabokov's extreme opinions about Freud can cause confusion. However, with a phenomenological approach (a kind of seeing and of hearing) we may learn that Nabokov's "caricature mirror" can educate us in unpredictable ways. ${ }^{6}$

\section{Phenomenological Analysis of the Elucidation of the Case; or: De-construction}

In this section, I will perform a de-construction of the above case. To summarise here what de-construction means or what it can mean, I will turn to the origin of the concept, which is to be found in the work of Martin Heidegger (rather than in that of Jacques Derrida, as many would have it). In the lecture, The Basic Problems of Phenomenology [Die Grundprobleme der Phänomenologie] that was given at the University of Marburg in the summer of 1927, Heidegger states:

[i]t is for this reason that there necessarily belongs to the conceptual interpretation of being and its structures, that is, to the reductive construction of being, a destruction - a critical process in which the traditional concepts, which at first must necessarily be employed, are deconstructed down to the sources from which they were drawn. (Heidegger, 1927/1988, p. 23; emphasis added)

By asserting that traditional concepts need to be de-constructed, one is not thereby enegaged in a total destruction of the tradition. De-construction contains both a destruction and a construction or both a negative and a positive understanding of critical inquiry. The negative aspect involves a destruction of certain falsifications of the traditional concept, while the positive one involves an invention or a recreation of the traditional concept. In short, deconstruction is a process of reinvention. Heidegger (1988) writes that: 
[c]onstruction in philosophy is necessarily destruction, that is to say, a deconstructing of traditional concepts carried out in a historical recursion to the tradition. And this is not a negation of the tradition or a condemnation of it as worthless; quite the reverse, it signifies precisely a positive appropriation of tradition. (p. 23; emphasis added)

This also means that we need to direct the phenomenological approach (a seeing and a hearing) toward the concept that is to be investigated, so as to let it speak for itself. We must in other words base our judgments on the experiences of the concept. It is not the case that we simply look closely at the particular concept in order to find its true meaning. Rather, Heidegger affirms "it must always be brought to view in a free projection” (p. 22).

Instead of explaining the "method" of de-construction further, I will rather demonstrate it through a further reading of Nabokov's treatment of Freud. The de-construction that will take place in my scene consists in overcoming the prejudiced picture of Nabokov as an author with strong "influence-anxiety" regarding Freud. Through a phenomenological approach I will destruct this image in order to recreate a new image of Nabokov's complex relation to the psychoanalyst. This image will be one that is very much related to education. The first step in the analysis will be to investigate whether the Nabokovian image of Freud is fraudulent or not. To do this I will direct my attention towards some of Nabokov's critics. I will try to address this particular question: How have some central critics of Nabokov received the novelist's treatment of Freud?

\section{A Short Reception History of Nabokov's Treatment of Freud}

The fact that Nabokov disliked Freud in several ways makes it tempting to read this relationship in light of Harold Bloom's theory of the anxiety of influence. ${ }^{7}$ If we take a look at how the novelist's dealing with the psychoanalyst has been received it usually comes down to one particular theme: namely, the anxiety of influence.

Jenefer Shute in the essay Nabokov and Freud says that Nabokov's relation to Freud can be explained by “a classic 'anxiety of influence' situation” (Shute, 1995, p. 416). By suggesting this, Shute indicates that Nabokov had a strong need to free himself from Freud because he did not want to end up as a footnote to his forerunner. In other words, Nabokov was fearful of not having the last word. "This nightmare - the nightmare of not having the last word - haunts all of Nabokov's works, and Pale Fire is only its most overt realization” (p. 416). According to Shute the novel Pale Fire (1962) clearly shows the situation of influenceanxiety. ${ }^{8}$

Bloom even claims that "the whole of part two of Lolita is an involuntary repetition of [Freud's] Beyond the Pleasure Principle” (1993, p. 3). Bloom thus indicates that Nabokov suffered from influence-anxiety against Freud or that he was envious of what Freud had and he himself lacked. Nabokov simply couldn't live with the fact that he would just end up as a replica of Freud. So what can a writer like this do to protect himself from this possible fate? He can, for example, turn to what Bloom in his famous book The Anxiety of Influence calls "daemonization," that is "to generalize away the uniqueness of the earlier work" (Bloom, 1997, p. 15). ${ }^{9}$ Given this, Nabokov would write in a rather veiled way because he wanted to explain away Freud's original premises. First, Bloom's point - that the second part of Lolita 
is merely an involuntary repetition of Freud's book Beyond the Pleasure Principle - lacks the analytic substance to make for a viable argument. Second, Bloom is wrong to indicate that Freud was a hero to Nabokov. We must not fall for the temptation of suggesting that "Nabokov secretly admire[d] and agree[d] with the Freud he [wa]s attacking," as Wood (1994, p. 121) puts it. That would only end up, Wood (p. 121) continues, as "a Nabokovian parody of a Freudian."

The argument used by Richard Rorty, in a very interesting essay entitled The Barber of Kasbeam: Nabokov on Cruelty, also contains limited analytic substance. He claims that "Freud was the one person Nabokov resented in the same obsessive and intense way that Heidegger resented Nietzsche. In both cases, it was resentment of the precursor who may already have written all one's best lines” (Rorty, 1996, pp. 153-154). Rorty's reading of anxiety of influence is not entirely supported either and is, I argue, an overstatement.

Not all Nabokov critics have read the treatment of Freud as an influence-anxiety. The well-known Nabokov biographer, Brian Boyd, challenges "Freudians to explain any form of human behaviour with absurd and worthless ease in terms of Freudian theory” (Boyd, 1991, p. 435). Boyd here turns his back on Freud, whilst he takes sides with Nabokov:

Not only did he [Nabokov] have a fierce sense of his own independence and a corresponding disinclination to wear someone else's [Freud's] ill-fitting mythic masks, not only did he have both an extraordinarily precise memory of his early childhood that he had good reason to trust better than Freud's [...]. (p. 160; emphasis added)

One of the new generation critics of Nabokov, Leland De la Durantaye, recently stated that

all of the influential first-generation critics of Nabokov 'side' with him. Stegner does so [...] as will, a few years later, Field [...]. Appel will continue in this same line, but most extreme in this respect is Boyd, who goes to some lengths to insult Freud. (2007, p. 124)

These Nabokov readers (Page Stegner, Andrew Field, Alfred Appel Jr., and - not the least Brian Boyd) have, De la Durantaye indicates, accepted at face value Nabokov's heavy critique of Freud and have taken sides with the novelist. Paradoxically, though, De la Durantaye himself has taken sides with Nabokov against Freud. The latter of the two is seen, from the point of view of De la Durantaye, as the enemy of detail, a matter very near to Nabokov's heart. For example, in the following, he states: “[i]n his [Freud's] writing - above all in his case histories - there is fantastic attention paid to the most minute and seemingly derisory detail of his patients' lives. And yet, this attention to the individual detail is coupled with a tireless drive to interpret those details within psychic schemas” (p. 125). Elsewhere he says (with regard to the book Leonardo): "More than anything else, this seems to lie in Freud having reached his conclusions about Leonardo's character before coming across the childhood memory upon which he based his analysis” (p. 128; original emphasis).

The insights provided by these Nabokov critics indeed weaken the probability of my assumption that the Nabokovian caricature imagery may lead to an educational insight where Freud is seen in a new and different light. Rather, they have claimed the very opposite. As for Boyd and De la Durantaye, they both strongly indicate that Nabokov's image is justified and that Freud really is, in certain texts of his, a deterministic thinker. That is their final 
conclusion. Thus they also presume that the Nabokovian image of Freud is not complicated at all. To them, the image is clear as crystal. In this paper I disagree. Both critics reduce Freud to a psychoanalyst who makes generalisations. Undoubtedly there is a lot of generalising in several of Freud's texts, including Leonardo, but all in all I think that Boyd and De la Durantaye have been fooled by Freud - or, more likely, they have been deceived by Nabokov's seemingly one-sided reading of the Viennese psychoanalyst. In particular Boyd never grabs hold of the complexity of the texts written by Freud. He only sticks to the simplicity. At least De la Durantaye tries to do justice to Freud as he recognises the psychoanalyst's “derisory detail of his patients' lives,” but - alas - the Nabokov critic comes to the conclusion that Freud did surrender to general ideas. Besides, De la Durantaye chooses to read Freudian texts which were written quite early in Freud's career. The later texts, especially those after the year 1919, are much more complex and open-ended than these earlier texts (however, let us not be deceived. Freud is, overall, a complex writer, and we will also find a lot of refined dialectics and delicate use of paradoxes in his earlier texts). These words of mine are, I have to accept, so far in lack of support. In order to support my counterresponse I am in need of knowledge, and what better place to gain knowledge than Freud's own texts? Let us henceforth direct our attention towards Freud himself.

\section{From the Point of View of Freud}

One of my goals at this point is to demonstrate that Nabokov's negative treatment of Freud is possible and not just a fantasy image drawn out of the blue. Thus I will first turn to the book Leonardo wherein we find many general ideas. Freud's aim in this book is to give psychological reasons as to why Leonardo da Vinci was homosexual. Freud begins by turning to a childhood memory of da Vinci's (as the title of the book suggests). Here is the memory:

It seems that I was always destined to be so deeply concerned with vultures; for I recall as one of my very earliest memories that while I was in my cradle a vulture ${ }^{10}$ came down to me, and opened my mouth with its tail, and struck me many times with its tail against my lips. (Freud, 1989, p. 82)

Freud acknowledges the value of symbols as he regards the word tail as a substitute for the male genitals: "A tail, 'coda', is one of the most familiar symbols and substitutive expressions for the male organ" (p. 85). Thus he can conclude that the opening of the mouth means "a sexual act in which the penis is put into the mouth of the person involved” (p. 86).

Such stale, mechanical and, indeed, comic images come as a gift to any caricaturist, who has a good eye for exaggerated traits. The caricaturist usually does not bother to consider traits that modify the exaggerated ones. The same goes for Nabokov. He magnifies and amplifies all the weaker parts of Freud. Nabokov draws a clown who stumbles and falls because he clings to a deterministic world. But that image is inadequate and deceitful. Nabokov entirely overlooks, so it seems, the profound traits of Freud. These traits are to be found, as I have said, in all of Freud's oeuvre but they are better shown in his later texts. Let us therefore look into one of these texts in order to deconstruct the traditional image of Freud that is given to us by Nabokov and his followers.

By looking into Freud's (quite controversial) book Beyond the Pleasure Principle (1920) a totally different image of Freud appears than the reduced image painted by Nabokov and his followers. We start to see that Freud is highly sceptical about his earlier viewpoints. He is full 
of doubt and does not take anything for granted. Hear what the psychoanalyst says himself: "We must be ready, too, to abandon a path that we have followed for a time, if it seems to be leading to no good end" (Freud, 1975, p. 64). This Freud is anti-Cartesian because he gives no promise of certainty, no quick answers, no final conclusions. At the same time he is open towards the future, he wishes to see what the future may bring. And he tries to do so by going backwards to rework and rephrase old understandings and apprehensions. In other words, Beyond introduces a new era with regard to the texts of Freud. From the year 1919, when Freud began to write Beyond, psychoanalysis is everything but an authoritative tool which gives clear answers. Quite the contrary, the "method" has become highly uncertain, and so indeterminate that Freud did not dare to believe his new thoughts:

It may be asked whether and how far I am myself convinced of the truth of the hypotheses that have been set out in these pages. My answer would be that I am not convinced myself and that I do not seek to persuade other people to believe in them. Or, more precisely, that I do not know how far I believe in them. (p. 59)

Freud does not close his text, Beyond, by an inference or a firm conclusion. Hence he could diverge from his earlier viewpoint on the theory of libido, a divergence that would lead him to write creative texts like The Ego and the Id (1923), Inhibitions, Symptoms, and Anxiety (1926) and Analysis Terminable and Interminable (1937).

This new image of Freud can be supported by a second-hand source. I am thinking of Bloom's book Agon. Therein he says that Freud had eventually begun to defend himself against his earlier texts: "Freud wrote no definitive, single text; but the canon of Freud's writings shows an increasingly uneasy sense that he had become his own precursor, and that he had begun to defend himself against himself" (Bloom, 1982, p. 118). Furthermore, the Freud of Beyond carries out "a double clinamen" which is "an ironic swerve away both from the pre-1919 Freud and from the visions of Schopenhauer and Nietzsche” (p. 129). Freud makes two renewals according to the American critic. First, he changes and renews his own thoughts before the year of 1919. Second, he readjusts and diverges away from certain philosophical thoughts descending from Schopenhauer and Nietzsche.

This is a totally different image of Freud than that painted by Nabokov. As a matter of fact it is almost a totally opposite image. Whilst Nabokov is painting a clown, Bloom is painting a critic who is also inventive. Surely there must be something false with Nabokov's painting of Freud? In one sense the Nabokovian image of Freud is not false. Freud's symbolism can, for sure, be quite stale and mechanical. The same image is, however, false in the sense that it is absolutely exaggerated. Thus the image is both similar and dissimilar to Freud, and that is why we have before us a caricature of a deceiving image, which may give us a different portrait of Freud. Let me elaborate more on this.

\section{Caricature and the Comic}

In his essay Good Readers and Good Writers Nabokov says:

Every great writer is a great deceiver, but so is the arch-cheat Nature. Nature always deceives. From the simple deception of propagation to the prodigiously sophisticated illusion of protective colors in butterflies or birds, there is in Nature 
a marvellous system of spells and wiles. The writer of fiction only follows Nature's lead. (1980, p. 5)

In Strong Opinions he says the same but with different words: "The sleight-of-hand [...] is hardly more than an insect's sleight-of-wing” (Nabokov, 1973, p. 153). Since Nabokov was a follower of the mimicking and deceptive ways of Nature I will suggest that his negative treatment of Freud turns into flash colouration. This is a phenomenon that happens in Nature, for example among moths and butterflies. The colourful Io moth (Automeris io) or Peacock moth is a first-class example. When this moth is frightened its forewings are usually drawn forward so as to display an eye pattern of imitation on the hind wings. Hence it gives the moth an appearance of being both larger and more dangerous. This flash colouration can either scare away predators or at least confuse them (giving the moth enough time to escape).

A similar deceit also happens in Nabokov's dealing with Freud. The novelist is imitating Freud, whilst he grossly exaggerates certain distinctive features with intent to ridicule. For this reason, the image possesses typical characteristics of a caricature. According to Johannes Climacus, one of Søren Kierkegaard's pseudonyms, "[t]he caricature must resemble a person, indeed, an actual, specific person” (Kierkegaard, 1846/1992, p. 517). Nabokov's image does resemble Freud, and yet it does not. As we have seen, Nabokov only ridicules Freud's generalisations and use of symbols. In other words, he is aiming his criticism against his predecessor's Achilles' heel, his most vulnerable point. At the same time something in the image is rejected and taken back. On the one hand we have Nabokov's mocking of Freud, the exaggeration, and on the other hand we have that which is withdrawn. That is why the same image is comic. Climacus explains: "Caricature is comic. By what means? By means of the contradiction between likeness and unlikeness” (p. 517). If the image does not resemble no one at all, "it is not comic but a direct attempt at a meaningless fantasy" (p. 517). With that in mind, I would like to say two things. First, the caricaturing of the psychoanalyst becomes a deception and an attempt to lure the reader into clichés and misrepresentation. Second, the same image invites humour and laughter due to its caricatured traits. In the prolongation of this latter assumption, humour may encourage a process of education wherein the receiver is given a chance to adjust the distorted image of Freud. We should therefore look more closely into the humourous parts of the caricature.

\section{Humour, Laughter, and Education}

Theorists of humour generally agree that there are three main theories of humour (Boyd, 2004, p. 3). ${ }^{11}$ There is the superiority theory. According to this theory we laugh because we feel a joy at being superior to others (p. 4). There is also the relief theory, which is most associated with Herbert Spencer and Freud. The latter has investigated humour in two texts, first in Jokes and Their Relation to the Unconscious (1905) and later in the essay Humour (1927). Humour is here seen as a way to release or save energy generated by repression (Boyd, 2004, p. 4). It would be, I must confess, tempting to use the relief theory so that I could look into Nabokov's treatment of Freud from the point of view of Freud himself. However, I will not. The reason is that Freud thinks laughter is first and foremost a therapeutic matter. I am more interested in investigating the educative effects that the caricature image may release. Thus I will turn to the incongruity-resolution theory of humour.

"The comic is," Climacus says, "present in every stage of life [...] because where there is life there is contradiction, and wherever there is contradiction, the comic is present" 
(Kierkegaard, 1846/1992, pp. 513-514). That is the simple law of the comic in regard to Climacus's incongruity-resolution theory of humour. Here is an example:

When a soldier stands in the street staring at the glorious window display in a fancy gift shop and comes closer in order to see better, when with his face really aglow and his eyes fixed on the finery in the window he does not notice that the basement entrance extends out inordinately far so that he vanishes into the basement just when he is about to have a proper look. (p. 516)

In this case the comic incongruity lies in the movement, that is to say, in the contradiction between the head and gaze that are directed upwards and his vanishing downwards into the basement. It is possible that we would laugh even though this man did not gaze upwards but the contradiction makes it more ludicrous. Thus it is more comic when a man looks at the stars in heaven and falls into a hole than a man just falling into a hole.

This background helps explain Nabokov's treatment of Freud. We have already seen that Nabokov of Lolita is ridiculing Freud, for example his emphasis on the sexual aspects of the unconscious. Similar things happen in Pale Fire. Here the fictitious character Charles Kinbote tells the reader that he has taken notes from a psychoanalytic book, used in American colleges: "By picking the nose in spite of all commands to the contrary, or when a youth is all the time sticking his finger through his buttonhole . . . the analytic teacher knows that the appetite of the lustful one knows no limit in his phantasies" (Nabokov, 1991, p. 635). Then he adds: "Do those clowns really believe what they teach?” (p. 635; original emphasis). What is ridiculous is that Freud and his followers interpret everything as sexual lust, even picking the nose or constantly sticking the finger through one's buttonhole are expressions of lust for sex. The comic incongruity here is that we recognise Freud while we simultaneously see that the image is blown out of all proportion. Now, if the image did not look like Freud it would be less comic because it would lack the necessary contradiction. Likewise, if the image was not exaggerated, but tried to resemble Freud perfectly, it would also be less comical because the image that we see through our imagination would not contain any inconsistency. However, if the image looks too serious it would be comic.

So why might we laugh when Nabokov is poking fun at Freud? The answer cannot be explained by one thing because people are different and our moods can shift from hour to hour, etc. Seen from the viewpoint of Climacus, we might say that the case invites laughter due to its incongruity and contradiction. Of course this may be explained differently if we were to choose other theories of laughter.

In a Bergsonian perspective the reason for laughing at the Nabokovian image of Freud may be that we detect "a certain mechanical inelasticity" (Bergson, 1956, p. 67; original emphasis). Laughter is aroused, according to Henri Bergson, when a person does not behave as s/he should; when "something mechanical [is] encrusted upon the living" (p. 92). A good example is a man who is about to sit on a chair, but falls on the floor because the chair has been moved. The man acts in accordance with habit, that is, he expected the chair to be at its regular place but it was moved without his knowing. The comic incongruity hinges on two things. First, our expectation that the man will behave in a flexible manner and see that the chair has been moved from its regular place, and second, the fact that he has taken for granted that the chair will be at its regular place. As a result of his mechanical act he falls to the floor, which may evoke laughter. Nabokov, too, has seen the inflexibility in Freud and has turned 
him into a comical thinker. Nabokov's Freud acts automatically; his decision is taken, he has made up his mind, once and for all. So whenever Nabokov is ridiculing the symbolic world of Freud it is easy to laugh because of the incongruity between the inflexible and mechanical and the flexible and the dynamic.

Bergson (1956) also believes that laughter adjusts and rectifies. The laughable is a sign of sickness and the laughter itself cures the sickness; laughter brings what is motionless into motion again (p. 188). Laughter, from a Bergsonian point of view, is like vomiting. When we have eaten deleterious food we may vomit and get rid of the deleterious substances. In plain words, we strive to get rid of the mechanical that is encrusted upon the living and try to set things in motion again. This process is educative in the sense that the first image, which caused laughter, is adjusted and seen differently afterwards. Laughter makes one realise that the Nabokovian image of Freud is false, just as those patterns on the Io moth are not eyes. Furthermore, one adjusts the image, makes it more just, so as to avoid falling into prejudice.

Climacus's educational aspect is different and more fruitful, I argue, than Bergson's. The perspective of Bergson regarding the educational effect of laughter may be viewed as dualistic because the person that laughs is changing the motionless image into a moving one. The person tries to rationalise the ludicrous image. In mediating what is comical into rational unity, the person steps outside of the humourous aspect of the image. Climacus, on the other hand, is not dualistic but dialectic in the sense that humour does not illuminate something objectively. The humourist in Climacus's perspective does not get rid of the inflexibility as though it was a kind of sickness: rather, s/he stays between the flexible and the inflexible. It would be like laughing at the circus clown. First you laugh at everything in his bag of tricks, everything from cake throwing to stumbling and falling down, then, after a while, you might begin to dwell on the act and start to see that the clown actually camouflages his suffering. You will notice a smile of sadness. The tears are hidden behind a smile. As a Climacian humourist one stays on the border between the ludicrous and the serious, or, from a slightly different angle, one is able to see the suffering in the preposterous and vice versa. As for the Nabokovian image of Freud, the Climacian humourist is able to see the contradiction between the flexible and inflexible Freud. And the reason is that Nabokov has given the reader an indirect helpful hand through the ridiculing of Freud. In other words, the Russian-American author has not said directly that Freud was more than a clown. He has said it indirectly, through rhetorical caricature and humour. A too serious person, someone like Boyd or De la Durantaye, will not be able to catch this because no attention is paid to the silence in Nabokov's communication. All their attention is paid to the too obvious in the Nabokovian image of Freud. The Climacian humourist, on the other hand, is able to hear what is said through silence. To this issue I will now turn, so as to round up my main argument.

\section{Educative Silence}

In a newspaper article Kierkegaard writes about Bishop Martensen's silence in regard to his heavy attack on the established view of Christendom:

Wherever there is the ludicrous, so declares one of my pseudonyms [Johannes Climacus], there is also a contradiction. It is the same with silence. A silence can have many different characteristics tending toward good or evil, but silence is ludicrous when it has the exasperating characteristic - that speaks. This is very ludicrous: a silence that speaks, 
speaks very loudly, and says what it is concealing so that everyone can hear it, says precisely what one wishes to hide with the help of silence. (Kierkegaard, 1855/ 1998, p. 80)

Heidegger, whose thoughts often coincide literally with Kierkegaardian propositions, almost repeats these words in Being and Time (1929): "But to keep silent does not mean to be dumb. On the contrary, if a man is dumb, he still has a tendency to 'speak'” (Heidegger, 1929/2003, p. 208). On the one hand a person can be silent as a clam. In consequence, the person is passive and the silence does not "speak." On the other hand, though, it is possible to "speak" without speaking. This background may broaden our understanding with regard to Nabokov's caricature image of Freud.

As previously stated, Nabokov is drawing or imitating Freudian peculiarities that are deliberately exaggerated to produce comic effects. We hear him clearly because, in a manner of speaking, he shouts out that Freud is a fool; hence his communication has the form of directness. However, he also communicates indirectly. How? Michael Wood gives us a clue:

But it is clear that Nabokov's making Humbert a sort of Freudian malgré lui deepens the apparently silly contest. Nabokov, let's say, would be the sceptic Humbert can't manage to be; a sceptic who knows there is something to be disbelieved: a false or ludicrous view of serious things. Freud is more of a rival than he looks, and needs to be caricatured as the fool who rushes in where Nabokov plans delicately to tread. (Wood, 1994, p. 121)

Nearly enough, Wood is close to the influence-anxiety reading because he claims that Freud is a rival. Nevertheless, Wood's statements can give support to my own claim. Notice that he states that Nabokov is "a sceptic who knows there is something to be disbelieved," and that Freud "needs to be caricatured." This tells us that the novelist doesn't believe that Freud is only a fool, but he refuses to say it aloud. Rather, he is saying it through the silence that is embedded in the caricature.

This background can, in fact, help in binding my above arguments together. On the one hand I have argued that Nabokov's caricature image stems from Freud's weaker parts, such as his, one could say, 'ludicrous' interpretations of symbols. On the other hand I have argued that Freud went far beyond his determinism, and transformed himself into a profound thinker. Consequently there is silence in the shouting. In other words, when Nabokov shouts that Freud is a fool there is also a silence. And the strange thing is that this silence "speaks." The silence "speaks" against the directness of that which is communicated. Nabokov thereby communicates different "messages" that contradict each other.

For this reason, Nabokov is a kind of teacher who stands in opposition to a rational teacher. The latter is transparent and can be seen through because the communicated message is crystal clear. To only send the message "Freud is a fool!" would imply that the receiver should passively take in the message. And since the teacher would not provide any resistance, the receiver would not have to struggle with the message. The process of education (and I am challenging strict definitions of the term) would require no action at all. As a caricaturist, however, Nabokov provides resistance because his communication contains the difference between that which is shouted ("Freud is a fool!") and the silence (that "speaks"). It can be very difficult to "uncover" this contradiction, though, because Nabokov shouts so loudly. The 
reader who gives an ear to the silence, though, may perceive that there is something beyond the principle of what Nabokov seemingly states. At the same time the reader may start out on an educational journey which begins with the difference between what is said directly and what is said indirectly. That place, which is created due to Nabokov's rhetorical caricature, is, I argue, the beginning of education because it releases the possibility to appropriate and recreate the Nabokovian image of Freud - or any reified understanding, by employing this stylistic method of rhetorical caricature.

A traditional and dominant perspective in education is that teachers should be precise in the communication of information. This idea harkens back to the Enlightenment idea of reason. Nabokov has taken issue with that form of communication because the teacher puts things in plain words and gives explanations and the like, whilst the student becomes an obedient listener. For this reason, direct communication limits and controls the lives of the students. Nabokov's rhetorical caricature, on the other hand, contains both flexible and inflexible forces, causing a tension between the two forces. Hence, it makes us laugh and encourages us to stop and hesitate on our journey of education, and - in the prolongation of that - it compels us to review our prejudiced expectations, or reified notions, and consequently to see and hear what we did not expect.

\section{End Notes}

${ }^{1}$ Also pointed out by Jeffrey Berman (1993, p. 110).

${ }^{2}$ Nabokov relates to the name Annabel Lee by writing Annabel Leigh. The two names sound the same, but we can see a slight difference. In other words, he performs an act of mimicry. Derrida did the same, although much later, when he wrote "differance" instead of difference.

${ }^{3}$ Humbert is attracted to certain girl-children between the age of nine and fourteen. This type of girl is called a "nymphet" (Nabokov, 1971, p. 18).

${ }^{4}$ Leonardo da Vinci was, according to de Vries and Johnson, "the artist Nabokov probably admired most” (de Vries \& Johnson, 2006, pp. 13-14).

${ }^{5}$ Here is a closer look at Freud's analysis for finding the cause to Leonardo da Vinci's claimed homosexuality. The analysis starts off with the fact that da Vinci was raised without a father. Therefore he had to identify himself with his mother. This would lead him to use himself as a model for the persons he would come to love. So these persons must be the same gender as he. That is, they must be replacements of himself as a child. As such he can love these boys or men in the same way his mother loved him when he was a child. Hence he evades developing an interest in other women. Why? Because he is afraid of being unfaithful to his mother (Freud, 1989, pp. 54-55).

${ }^{6}$ It is not possible, however, to reveal the secrets totally. This claim is supported by Nabokov where he speaks of reality: "You can get nearer and nearer, so to speak, to reality; but you never get near enough because reality is an infinite succession of steps, levels of perception, false bottoms, and hence unquenchable, unattainable [...] we live surrounded by more or less ghostly objects” (Nabokov, 1973, p. 11). 
${ }^{7}$ In the preface of the book The Anxiety of Influence Harold Bloom sums up his theory of influence-anxiety. He says: "What matters most (and it is the central point of this book) is that the anxiety of influence comes out of a complex act of strong misreading, a creative interpretation that I call 'poetic misprison'” (Bloom, 1997, p. xxiii). In other words, the strong poet or the ambitious writer has influence-anxiety with regard to earlier writers (especially Shakespeare) which might lead to a creative reading of texts. John Keats for example, created his characteristic Ode on a Grecian Urn through a strong misreading of earlier poets, such as Shakespeare, Milton and Wordsworth.

${ }^{8}$ Let us take a look at the novel Pale Fire in order to understand the argument of Jenefer Shute. Like the relation between Freud and Nabokov, Pale Fire is about a relation between a dead writer, John Shade, and a reader/writer, Charles Kinbote. The latter of these two struggles against the author - Shade, and it is a struggle of having the last word. The sly fox, Kinbote, brings this hypothesis into the foreword: "[...] it is the commentator who has the last word” (Nabokov, 1991, p. 25). Is this hypothesis, however, true? Not quite. It certainly seems as if Kinbote, the commentator, gets the last word when he puts his very extravagant distinctive stamp on Shade's work of poetry (see, for example, Field, 1967, p. 298; Pifer, 1980, p. 113), which is called Pale Fire. But it is Shade, the dead poet, who gets the last word. I am not the only theorist who claims this. David Rampton, for example, states: "Fate will arrange for him [Shade] to live on in his poems. Someone will rescue and republish 'Pale Fire', and the commentator [Kinbote], his design thwarted, will not get the last word after all” (Rampton, 1984, p. 155). In the end it is Shade who gets the last word. Said differently, the words of Shade outshines Kinbote's words, or, the text is taking Shade out of the shade. The most extraordinary of this example is that the forerunner seems to get the last word even though Kinbote strives to have the last word. Rampton even goes on to say that Kinbote, at certain places, omits to manipulate Shade's words, so that he himself "comes out a distinct second-best” (Rampton, 1984, p. 155). In other words, the successor does not even try to surpass his predecessor.

${ }^{9}$ According to Bloom's theory of poetic influence there are six different ways of reading which are called "Revisionary Ratios” (Bloom, 1997, pp. 14-16).

10 We now know that Freud mistranslated the word nibbio, which "means 'kite', not 'vulture'”' (Gay, 1989, p. xxiii).

${ }^{11}$ However, the three main theories of humour do not explain everything with regard to humour: rather, they overlap each other.

\section{References}

Bergson, H. (1956). Laughter. In W. Sypher (Ed.), Comedy. New York: Doubleday Anchor Books.

Berman, J. (1993). Nabokov and the Viennese witch doctor. In H. Bloom (Ed.), Lolita. New York: Chelsea House Publishers. 
Bloom, H. (1982). Agon. Towards a theory of revisionism. Oxford: Oxford University Press.

Bloom, H. (1993). Introduction. In Bloom, H. (Ed.) Lolita. New York: Chelsea House Publishers.

Bloom, H. (1997). The anxiety of influence. A theory of poetry. Oxford: Oxford University Press.

Boyd, B. (1991). Vladimir Nabokov. The American years. Princeton: Princeton University Press.

Boyd, B. (2004). Laughter and literature: A play theory of humor. Philosophy and literature, 28, $1-22$.

de Vries, \& Johnson, D.B. (2006). Nabokov and the art of painting. Amsterdam: Amsterdam University Press.

De la Durantaye, L. (2007). Style is matter: The moral art of Vladimir Nabokov. Cornell: Cornell University Press.

Field, A. (1967). Nabokov: His life in art. London: Hodder and Stoughton.

Freud, S. (1975). Beyond the pleasure principle. In J. Strachey (Ed.), The standard edition of the complete psychological works of Sigmund Freud, vol. XVIII. London: The Hogarth Press and the Institute of Psycho-Analysis.

Freud, S. (1989). Leonardo and a memory of his childhood. In J. Strachey (Ed.), Leonardo and a memory of his childhood. New York: W.W. Norton \& Company.

Gay, P. (1989). Sigmund Freud: A brief life. In J. Strachey (Ed.), Leonardo and a Memory of his Childhood. New York: W.W. Norton \& Company.

Heidegger, M. (1927/1988). The basic problems of phenomenology. Bloomington and Indianapolis: Indiana University Press.

Heidegger, M. (1929/2003). Being and time. Oxford: Blackwell Publishing Ltd.

Kierkegaard, S. (1846/1992). Concluding unscientific postscript to philosophical fragments, volume I. In H. V. Hong \& E. H. Hong (Eds.), Kierkegaard's writings, XII.1. Princeton, New Jersey: Princeton University Press.

Kierkegaard, S. (1855/1998). The moment and late writings. In H. V. Hong \& E. H. Hong (Eds.), Kierkegaard's writings, XXIII. Princeton, New Jersey: Princeton University Press.

Nabokov, V. (1971). Lolita. In A. Appel, Jr. (Ed.), The annotated Lolita. New York: McGraw-Hill.

Nabokov, V. (1973). Strong opinions. New York: McGraw-Hill Book Company. 
Nabokov, V. (1980) Good readers and good writers. In F. Bowers (Ed.), Lectures on literature. New York: Harcourt Brace Jovanovich.

Nabokov, V. (1991). Pale fire. London: Penguin Books.

Nabokov, V. (1996a). Bend sinister. In B. Boyd (Ed.), Nabokov: Novels and memoirs 19411951. New York: The Library of America.

Nabokov, V. (1996b). Speak, memory. In B. Boyd (Ed.), Nabokov: Novels 1955-1962. New York: The Library of America.

Pifer, E. (1980). Nabokov and the novel. Harvard: Harvard University Press.

Rampton, D. (1984). Vladimir Nabokov-A critical study of the novels. Cambridge: Cambridge University Press.

Rorty, R. (1996). Contingency, irony, and solidarity. Cambridge: Cambridge University Press.

Shute, J. (1995). Nabokov and Freud. In V. E. Alexandrov (Ed.), The garland companion to Vladimir Nabokov. New York \& London: Garland Publishing, Inc.

Stegner, P. (1966). Escape into aesthetics: The art of Vladimir Nabokov. New York: Dial.

Sæverot, H. (2010). Educative deceit: Nabokov and the [im]possibility of education. Educational Theory 60(5), 601-619.

Wood, M. (1994). The magician's doubts: Nabokov and the risks of fiction. London: Chatto \& Windus. 